\title{
Role of Academic Audit in enhancing the employability of Management Graduates: A Case Study
}

\author{
Ms. Rashmi Saket Prasad, Research Scholar, JJTU, Rajashtan, India, \\ Dr. Shalaka Parker, Co Guide and Dean, DYPIMBA, Pune, Maharashtra, India.
}

\begin{abstract}
Purpose - To analyze and Study the use of Academic Audit as tool to make the Students of B Schools in Pune more employable

Keywords: Academic Audit, Academic Quality, Employability

Design/Methodology/Approach - This is a study of two Business Schools which are taken for study are the Institutes one which is actually practicing the Academic Audit as their normal routine and there is one Institute which is just doing it for the name sake. The name of the Institute is not disclosed of both the Institution as that will effect the image of such Institution. The Interview of the Business schools was done by personally visiting the Institute and understanding the way they have implemented the Academic Audit .Two B-Schools in Pune were approached: one a very reputed and branded institution (Institution A) and the other an average rated institution (Institution B).Academic leaders of these two B-Schools were interviewed to find out:

1. How the Academic Leaders are using Academic Audit to bring qualitative change in the Students

2. How the students are becoming employable by the effective implementation of Academic Audit?

3. How the teachers are using Academic Audit as a tool for preparing students industry ready
\end{abstract}

Findings - The Director of Institution A was a leader with excellent administrative skills, interpersonal skills, communication skills, a foresighted vision and mission for the institute, in-depth knowledge, avid experience and an insight into academics. The director believes that if we want to survive in the current academic competition we need to work with the pace of the world. The Director stated that If we cannot compete with the world at least first we must bring the standards of the Institute to the national level. Also the director provided information showing encouraging signs of addressing progress, via implementing effective academic audit systems in the Institute. Director explained that hoe the IQAC cell work throughout the academic year and the pints given by IQAC Cell are included in the implementation of Academic Audit.

The Institute conducts the Academic Audit rigorously and the teachers take the feedback given by the Auditors to improve the performance of the Students and prepare them for the Industry.

However, the Director of the Institution B, when interviewed was not even aware of the Academic Audit concept Infact the Institute was surprised to know the word academic audit itself. They have IQAC cell in place but they conduct the meeting just for the record purpose. The Academic Audit points are not included, they are more concerned about the monetary part. The organization is not taking effort to prepare the students ready for the study. Infact because of the poor placements record they are not getting quality students

\section{INSTITUTION A}

\section{A) Successful Implementation of Academic Audit in B-Schools under Study}

Academic audit in this Institute is conducted twice in a year. The Director of the Institute is given a free hand by the management to take decision for the betterment of the Institution and to prepare the students to get placed in reputed Company Successful academic leadership practices identified in the B-Schools

1. Inviting Industry people: The Institution feels that no one can be expert in the entire field so inviting speakers with proven expertise in a topic can provide added authority to our content. These experts are within the campus and also from the Industry. The Students get to hear something new and they feel happy to know what is happening new in the Industry or outside world. With the new style of delivering lectures the faculty members also learn new methods of teaching and pedagogy

\section{Enhancing Soft skills}

The Institution believes that Soft skills are an essential part of improving networking abilities, improve networking The institute categorize between the students with good communication skill and student with weak communication skill. The Students with good communication are made mentors of students with weak communication. The students with good communication skill are further trained for highly developed presentation skills, networking abilities, and etiquette awareness which help to improve their personality further. The proper training helps to face the real time which helps to 
develop the relationship skill so that the students are ready to face the challenges of the Industry. They learn to develop the skills to deal with their colleagues and managers and other professional contacts.

3. Internship programmes for students in reputed Institute/ Institute tie up with reputed organization to give internship to the students. It helps to improve the students' practical knowledge and they learn what is current in the market. They are able to implement their knowledge in the practical life. This bring confidence in the students, they learn about team building, the students improves their combination skills. If the interns perform well they often get chance to get placed in the organization. By working in Industry the students also develop their interpersonal skills. The students also get prepare to solve real time problem. The probability of placement also increases due to Internship training.

4. Encouraging Online Certification: Apart from the normal routine curriculum a lot of Online Certifications are available nowadays wherein you can learn a lot through these mediums. Online courses help the students to manage their studies as per their convenience. They learn the latest technology. As there are lots of certification courses available nowadays, all of them are not authenticated. The Institute recognizes valuable online courses and make it compulsory for the students. This becomes an added qualification for the students apart from their regular degree which helps in placements of the students.

5. Alumni Interaction The Institute has Alumni Cell which is actively involved in keeping a connect with the Alumni of the Institution. The Alumni are considered to be a very good source of connect to establish with Industry. The Senior Alumni which are well placed becomes a source for placements for the students. The Alumni are a role model for the students. The students get a feeling that they will also be placed in good companies like them The Alumni act as a bridge between the Industry and Academia.

5.Talk Show conducted by Students: The clear idea of this Institute is to inculcate habit of spreading Ideas .The Institute encourage this idea by organizing TED Talks by the Students. This help the Students to come with new ideas . This enhances the communication skill of the students. It improves public speaking skills. By practicing Talks the students understand the audience and develop the arts of drawing attention of the students. Students learn to connect with the students because connecting is more important than contents. Students learn delivering skills .By organizing Talk shows students explore new topics and they develop habit of continuous learning. The Institutes organizes this on every weekend and make all the students to deliver lecture turn by turn.

\section{Research Culture:}

A culture of Research requires both institutional- and Academic leaders to set clear Research goals and communicate them effectively. The goals must be accompanied by a well-defined plan of research success evaluation as well as any accompanying changes in compensation. Academic Leaders should also adjust job descriptions to include statements of research and teaching expectations. Institutions wishing to develop a culture of research must allocate significant resources for faculty training and support. Faculty with minimal scholarship production experience will likely need training and personal support to become proficient. Institutions may develop continuing education courses or support services in research practices, grant writing, and grant management. These programs could be housed in either a centralized or discipline-specific research center.

\section{Inviting students' suggestions to improve the standards of the organization:}

Students are the key stakeholders of any Educational Institution and brand ambassadors of the same. Thus, in their satisfaction about the quality of education received at the Institute denotes a very important feedback. Hence Students Feedback becomes a crucial element in any Academic Audit. Their feedback marks all the positives and negatives of an institute.

The Director of Institution A was instrumental in developing the habit of conducting Academic Audit in his institution by building a team culture and polishing the students by using abovementioned measures. The Director had taken conscious efforts to support faculty members, staff and students in times of crisis, had acknowledged good work, and engaged faculty members and students actively. He is also visible and accessible to faculty members, staff, students and parents, very readily and is always available to provide assistance as needed.

The Director of Institution A displayed a keen awareness pertaining to all the factors that are required for success of Academic Audit

\section{INSTITUTION B}

The Director of Institution B had pessimistic and not good enough inputs regarding the conduct of Academic Audit. The Director was not even aware of the factors that are required for conducting Academic Audit The Director was doing it just for the name sake. Taking the Academic Audit as just aformality for meeting the compliance of AICTE. He shared that there is lot of interference from the management side and that he is not working with free mind $\mathrm{He}$ is taking all the financial guidance from their management which is reducing the quality of teaching and hence the placements also gets affected. Certain practices that the Institute is adopting were: 
i. Ineffective communication between the head of institution, faculty members and Students.

ii. Alumni Resources are poorly managed and there is no such formal Alumni cell. The cell is just there for the name sake. There is no good connect between the Alumni and Institute

iii. The Director is never involved in quality assurance processes because the management does not feel the need for his involvement.

iv. This academic institution has only interest in students, they are never bothered about the quality students. They are more into the recovery of money so the purpose of these institutes is as a business center with the sole purpose of making money.

v. The institution B is under the extensive umbrella of the same management and needs to go in for sharing of resources, infrastructure facilities ,funds, which does not give an independent identity to either and keeps the WORKFORCE unhappy.

vi. There is no Skills training given to the students. Only the students syllabus is covered by classroom teaching.

vii. There is lack of advanced equipments for teaching and research.

viii. There is no effort taken by management for strengthening the Industry-Institute gap

ix. $\quad$ No efforts for the professional development of the faculty members and students. Etc.

\section{CONCLUSION}

Academic Audit brings discipline in the conduct of Academics. It is faculty driven model that bring self-reflection. It brings quality in Academics. The Institution which are using the academic Audit as a tool for enhancing the standards of the Institute is reflected in the placements of the students. The Institute that practices it on regular basis gets output in the form of students' placements. Regular Academic Audit gives feed-back about each faculty member in the form of self appraisal and appraisal from head of the institution to know their teaching and learning performance. The details of the subjects handled, percentage of pass and students 'performance in the tests and examinations, participation in faculty development programme, participation in the external conferences and seminars, books or papers published and programmes organized in the college. The observations from the audit are passed on to the

head of the institute for institutional improvement. Thus, It is obvious that, inclusion of employability development among students as the prominent component of academic auditing will focus many other academic and extra-curricular areas. The skills and knowledge to be developed under employability skills will improve other allied facets of individual student as well as the institute. Proper evaluation and working upon the feedback of the external auditors continuously will be really beneficial to the institutes. In the institutes where placement is the most important recognition, this experiment will be certainly fruitful.

\section{BIBLIOGRAPHY}

[1] Ancis, J.R., Sedlacek, W.E. \& Mohr, J.J., "Student Perceptions of Campus Cultural Climate by Race." Journal of Counseling and Development, (2000): 180-185.

[2] B.L.Gupta, Academic Audit, CONCEPT PUBLISHING HOUSE (1 June 2011), ISBN-10: 8180697371, ISBN-13: 9788180697371

[3] Bass, B. M., \&Avolio, B.J. (Eds.). (1994). Improving organizational effectiveness through transformational leadership..

[4] Caffarella, R.S. \&Zinn, L.F. (1999). Professional development for faculty: A conceptual framework of barriers and supports. Innovative Higher Education, 23(4), 241-254.

[5] Cambourne, B. (1989). Theory into practice. The whole story. Ashton Scholastic: Gosford.

[6] Dr. Neeta Baporikar, Management Education: Challenges Ahead- An Indian Perspective.

[7] Edward A. Kolodziej, Educate for Global and Local Citizenship,.

[8] Fazzi, C. (2008). Effective leadership can be learned. Dispute Resolution Journal, 63(3), 89- 91.

[9] Gunter, Helen M. (2001); Leaders and Leadership in education, sage publications.

[10] Internationalization of the Curriculum: A practical guide to support Canadian Universities' efforts. March 2009. Association of Universities and Colleges of Canada.

[11] Kuh, G. (1993). "In Their Own Words: What Students Learn Outside the Classroom." American Educational Research Journal 30, 277-304.

[12] Mari Ostendorf, University of Washington May 9, 2005. Mentoring for Academic Leadership,

[13] Mari Ostendorf, University of Washington May 9, 2005. Mentoring for Academic Leadership,

[14] Michael R. Moore, Michael, Academic Leadership Turning Vision into Reality, A. Diamond. The Ernst \& Young Foundation.

[15] Pondy, L.R. \&Mitroff, I.I. (1979). Beyond open systems models of organization. In

[16] B.M. Staw (Ed.) Research in organizational behaviour (pp.3-39), Greenwich: JAI Press. 